\title{
Inclusion and definition of acute renal dysfunction in critically ill patients in randomized controlled trials: a systematic review
}

Rogerio da Hora Passos ${ }^{1,3^{*}}$, Joao Gabriel Rosa Ramos ${ }^{1}$, André Gobatto ${ }^{1}$, Juliana Caldas', Etienne Macedo ${ }^{2}$ and Paulo Benigno Batista ${ }^{1}$

\begin{abstract}
Background: In evidence-based medicine, multicenter, prospective, randomized controlled trials (RCTs) are the gold standard for evaluating treatment benefits and ensuring the effectiveness of interventions. Patient-centered outcomes, such as mortality, are most often the preferred evaluated outcomes. While there is currently agreement on how to classify renal dysfunction in critically ill patients, the application frequency of this new classification system in RCTs has not previously been evaluated. In this study, we aim to assess the definition of renal dysfunction in multicenter RCTs involving critically ill patients that included mortality as a primary endpoint.

Methods: A comprehensive search was conducted for publications reporting multicenter randomized controlled trials (RCTs) involving adult patients in intensive care units (ICUs) that included mortality as a primary outcome. MEDLINE and PUBMED were queried for relevant articles in core clinical journals published between May 2004 and December 2017.

Results: Of 418 articles reviewed, 46 multicenter RCTs with a primary endpoint related to mortality were included. Thirtysix (78.3\%) of the trial reports provided information on renal function in the participants. Only seven articles (15.2\%) included mean or median serum creatinine levels, mean creatinine clearance or estimated glomerular filtration rates. Sequential organ failure assessment (SOFA) score was the most commonly used definition of renal dysfunction (20 studies; 43.5\%). Risk, Injury, Failure, Loss, End-stage renal disease (RIFLE), Acute Kidney Injury Network (AKIN) and Kidney Disease Improving Global Outcomes (KDIGO) criteria were used in five (10.9\%) trials. In thirteen trials (28.3\%), no renal dysfunction criteria were reported. Only one trial excluded patients with renal dysfunction, and it used urinary output or need for renal replacement therapy (RRT) as criteria for this diagnosis.
\end{abstract}

Conclusion: The presence of renal dysfunction was included as a baseline patient characteristic in most RCTs. The RIFLE, AKIN and KDIGO classification systems were infrequently used; renal dysfunction was generally defined using the SOFA score.

Keywords: Acute kidney injury, Critically ill, Intensive care unit, Mortality, Systematic review

\footnotetext{
* Correspondence: oiregorpassos@yahoo.com.br

${ }^{1}$ Critical Care Unit, Hospital São Rafael, Av São Rafael, Salvador 2152, Brazil

${ }^{3}$ Critical Care Unit, Nephrology Department, Hospital Portugues, Salvador,

Brazil

Full list of author information is available at the end of the article
} 


\section{Background}

Acute renal dysfunction affects one in five hospitalized patients [1] and occurs in up to $25 \%$ of critically ill individuals $[2,3]$. Renal dysfunction is an independent risk factor for mortality, especially in patients treated with renal replacement therapy (RRT) [4]. Recent epidemiological studies have shown that renal dysfunction is associated with prolonged hospital stay, increased hospitalization costs, and progression to chronic kidney disease $[2,5]$.

Since 2004, the severity of kidney injury has been determined by several new classification systems: Risk, Injury, Failure, Loss, End-stage renal disease (RIFLE), Acute Kidney Injury (AKI) Network (AKIN) and Kidney Disease Improving Global Outcomes (KDIGO) [6]. These systems have provided a standardized assessment of renal dysfunction severity and consistent estimates of epidemiological measures $[7,8]$. However, there is insufficient evidence to support their widespread application in critical care $[9,10]$. Furthermore, in critically ill patients, renal dysfunction severity can also be evaluated by combining renal function with functional parameters of other organs (e.g., the Sequential Organ Failure Assessment (SOFA) score) [11].

In evidence-based medicine, multicenter, prospective, randomized controlled trials (RCTs) are the gold standard for evaluating treatment benefits and ensuring the effectiveness of interventions. Patient-centered outcomes, such as mortality, are most often the preferred evaluated outcomes [12]. While there is currently agreement on how to classify renal dysfunction in critically ill patients [13], the application frequency of this new classification system in RCTs has not previously been evaluated. In this study, we aim to assess the definition of renal dysfunction in multicenter RCTs involving critically ill patients that included mortality as a primary endpoint. In addition, we evaluated the criteria used to determine the severity and progression of kidney injury.

\section{Methods}

\section{Search strategy and eligibility}

A comprehensive search was conducted for publications reporting multicenter RCTs involving adult patients in intensive-care units (ICUs), with mortality as a primary outcome. The search was conducted in the MEDLINE database via the PubMed interface, including articles in the core clinical journals subset published May 2004 to December 2017 (In the list below). MEDLINE offers the "Core Clinical Journals" filter to limit searches to clinically useful journals $[14,15]$. Eligibility assessment and data abstraction were performed independently in a non-blinded, standardized manner by two reviewers. Inter-rater reliability was evaluated using the kappa statistic. Discrepancies in methodological quality assessment and final classification of the RCTs were resolved by consensus among the authors. Comparison parameters included the definition and exclusion of patients with renal dysfunction, baseline serum creatinine levels, proportions of trial participants with renal dysfunction, and subgroup analyses involving acute renal dysfunction.

- 01 "intensive care"[MeSH Terms] OR Intensive care[Text Word]

- 02 "critical care"[MeSH Terms] OR critical care[Text Word]

- 03 ("critical illness"[TIAB] NOT Medline[SB]) OR "critical illness"[MeSH Terms] OR critically ill[Text Word]

- 04 "sepsis"[MeSH Terms] OR sepsis[Text Word]

- 05 "artificial respiration"[Text Word] OR "respiration, artificial”[MeSH Terms] OR mechanical ventilation[Text Word]

- 06 "adult respiratory distress syndrome"[Text Word] OR "respiratory distress syndrome, adult" $[\mathrm{MeSH}$ Terms] OR A RDS[Text Word]

- 07 (\#01OR\#02OR\#03OR\#04OR\#05OR\#06)

- 08 "randomized controlled trial"[Publication Type] OR "randomized controlled trials"[MeSH Terms] OR "randomized controlled trial" [Text Word] OR "randomised controlled trial"[Text Word]

- 09 \#07 AND \#08

- 10 ("Multicenter Studies"[MeSH] OR "Multicenter Study"[Publication Type]) OR multicenter[All Fields]

- 11. End Point Mortality

- 12 \#09 AND \#10

\section{Data extraction}

The following data were extracted: (1) subject of study, (2) number of patients, (3) number of centers, (4) conditions studied, (5) allocation concealment, (6) exclusion of chronic kidney disease, (7) exclusion of acute renal dysfunction, (8) chronic kidney disease (CKD) criteria, (9) baseline acute renal dysfunction criteria, and (10) acute renal dysfunction as outcome (11) mortality. Two authors (RHP and PB) evaluated the selected studies for quality using the Consolidated Standards of Reporting Trials (CONSORT) checklist.

\section{Statistical analysis}

Analyses were performed in SPSS 21.0 (SPSS, Inc.). Categorical variables are described as number (percentage).

\section{Results}

The selection and exclusion of RCTs are summarized in Fig. 1. Inter-observer agreement among the reviewers for the selection and final classification of the studies was high, with a kappa statistic of 0.86 . From 418 separate articles, 46 multicenter RCTs (including both single-continent and 


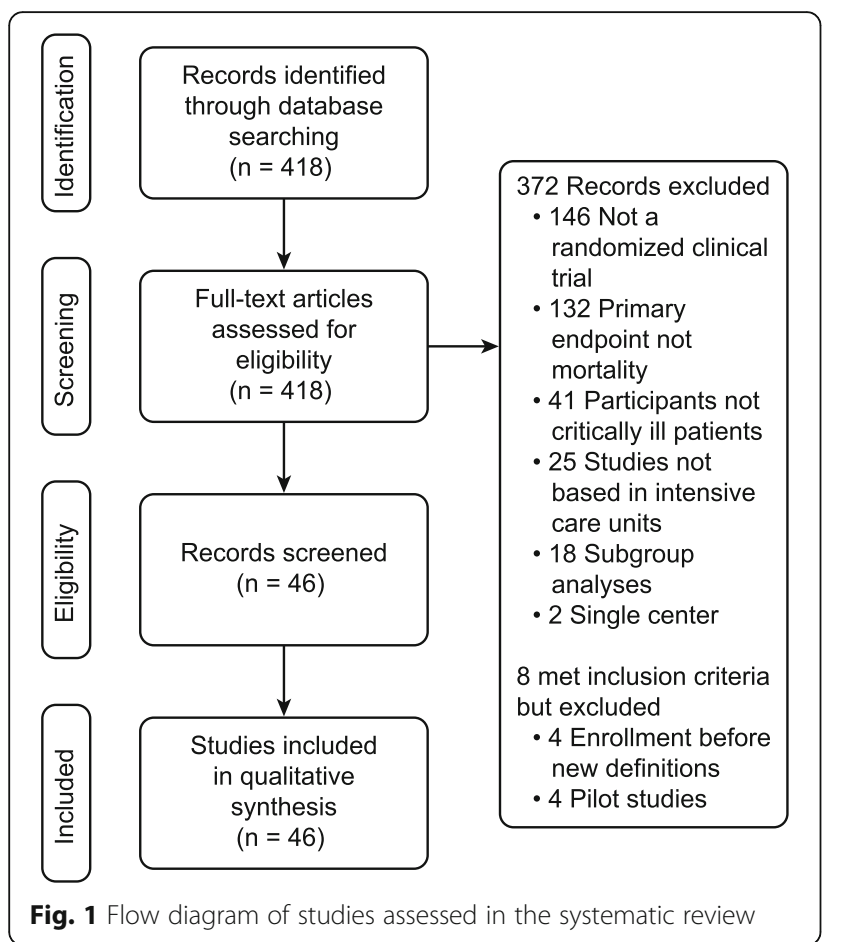

multi-continent settings) with a primary end point related to mortality were included [16-61]. Of these, 5 showed a beneficial effect of the trial intervention on mortality, whereas 41 demonstrated a neutral effect (Table 1).

$C K D$ chronic kidney disease, PEEP positive endexpiratory pressure; SOFA sequential organ failure assessment, $M V$ mechanical ventilation, $M O D S$ multiple organ dysfunction score, GFR glomerular filtration rate; $L O D S$ logistic organ dysfunction score, $U O$ urine output, $R R T$ renal replacement therapy, KDIGO Kidney Disease Improving Global Outcomes; RIFLE Risk, Injury, Failure, Loss of kidney function, End-stage kidney disease, TAK242 a small-molecule inhibitor of Toll-like receptor-4mediated, $A R D S$ acute respiratory distress syndrome, $I A B P$ intraaortic balloon pump, $\mathrm{Cr}$ creatinine

The distribution of the number of studies per year of publication, stratified by the acute renal dysfunction criteria used as a baseline and outcome measure is described in Figs. 2a and b, respectively (Fig. 2).

\section{Conditions studied}

A wide range of conditions in critically ill patients was studied in the $46 \mathrm{RCTs}$, including sepsis (13 RCTs), acute respiratory distress syndrome (11 RCTs), shock (5 RCTs), nutrition (4 RCTs), anemia (5 RCTs), surgery (3 $\mathrm{RCTs})$, respiratory failure (2 RCTs), pneumonia (2 $\mathrm{RCTs}$ ), renal replacement therapy (1 RCT), and quality improvement (1 RCT).

\section{Interventions}

The RCTs assessed a range of interventions in critically ill patients (Table 1), including drug treatment (22 RCTs), nutrition (4 RCTs), hemodynamic optimization (5 RCTs), transfusion (5 RCTs), mechanical ventilation (8 RCTs), timing of renal replacement therapy (1 RCT) and daily round checklist (1 RCT).

\section{Reporting of acute renal dysfunction in cohort characteristics}

Thirty-six trial reports (78.3\%) provided information on acute renal (dys)function in the participants. Only seven articles $(15.2 \%)$ contained mean or median serum creatinine levels, mean creatinine clearance or estimated glomerular filtration rates (eGFRs). The SOFA score was the most commonly used definition of acute renal dysfunction, in 20 studies (43.5\%): RIFLE/AKIN/KDIGO criteria were used in 5 trials $(10.9 \%)$. In thirteen trials $(28.3 \%)$ no criteria for defining acute renal dysfunction were reported. Only one trial (2.2\%) excluded patients with acute renal dysfunction, using urinary output or need for RRT as criteria for this diagnosis. As shown in Fig. 2, RIFLE/KDIGO/AKIN criteria were mostly used in recent years (2016 and 2017).

\section{Reporting of acute renal dysfunction in secondary outcomes}

Most of the trials studied acute renal dysfunction as a secondary outcome, which was reported in 33 trials (71.7\%). The renal SOFA score was the most commonly used definition, in 19 trials (41.3\%), followed by the need for RRT, used in 10 trials (21.7\%) and RIFLE/AKIN/KDIGO criteria used in 5 trials (10.9\%). Only six articles (13.0\%) included serum creatinine levels, mean creatinine clearance, or GFR (eGFR) values as secondary outcomes.

Five trials $(10 \%)$ reported progression to more severe stages of acute renal dysfunction. No trial reported progression to chronic kidney disease. Thirty-three trials (71.7\%) evaluated organ dysfunction in addition to renal dysfunction.

\section{Discussion}

Our results demonstrated that patients with acute renal dysfunction were often included in multicenter RCTs involving critically ill patients that included mortality as a primary endpoint. However, current classification systems, such as RIFLE/AKIN/KDIGO, were not frequently used to define renal dysfunction in the descriptions of patient baseline characteristics or as secondary outcomes.

Despite the advances from widespread use of new classification systems and the development of new biomarkers for early renal dysfunction detection, little progress has been made in developing evidence-based interventions for renal dysfunction prevention and treatment [10]. For critically ill patients, the lack of positive results may be related 


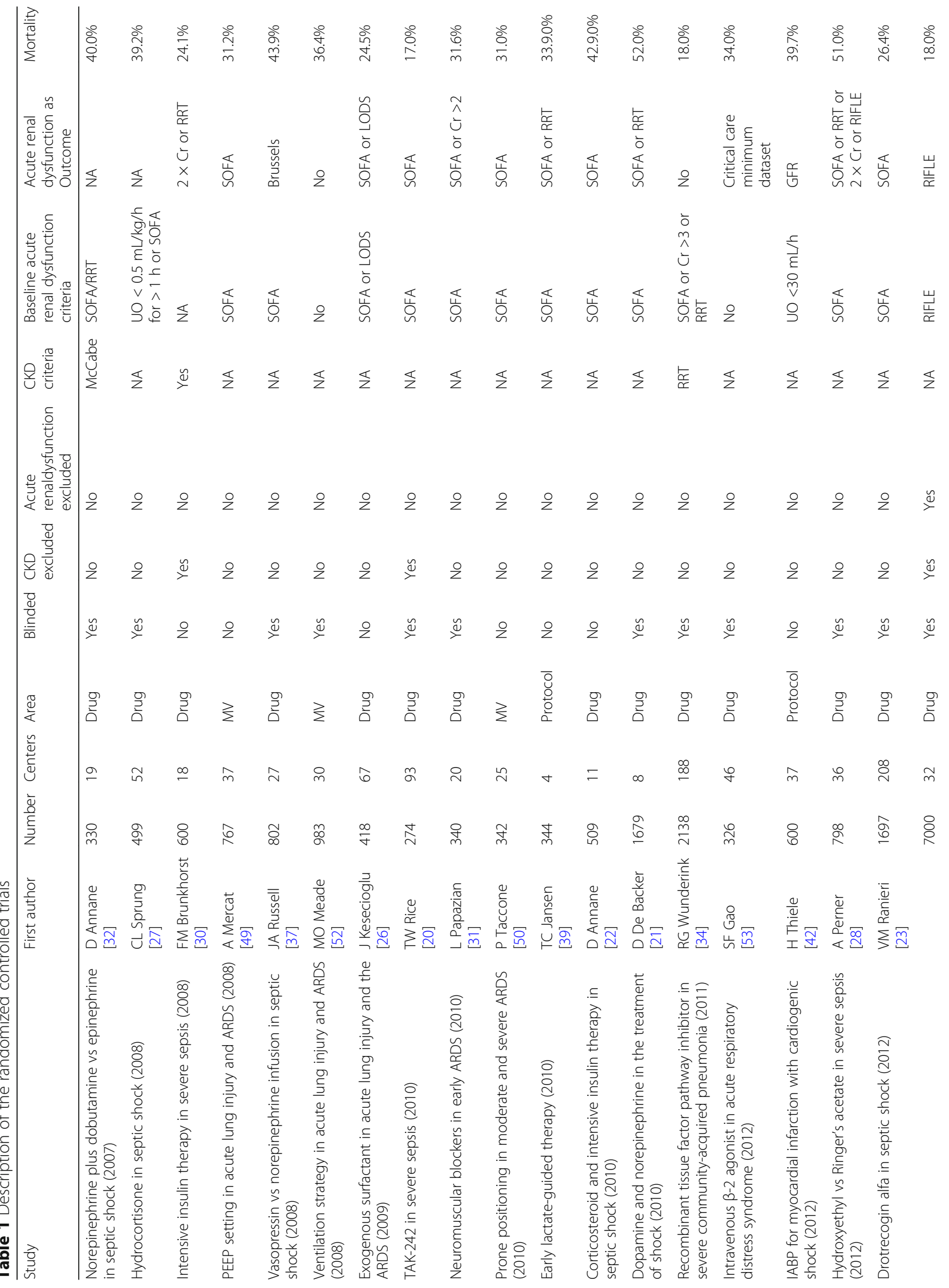




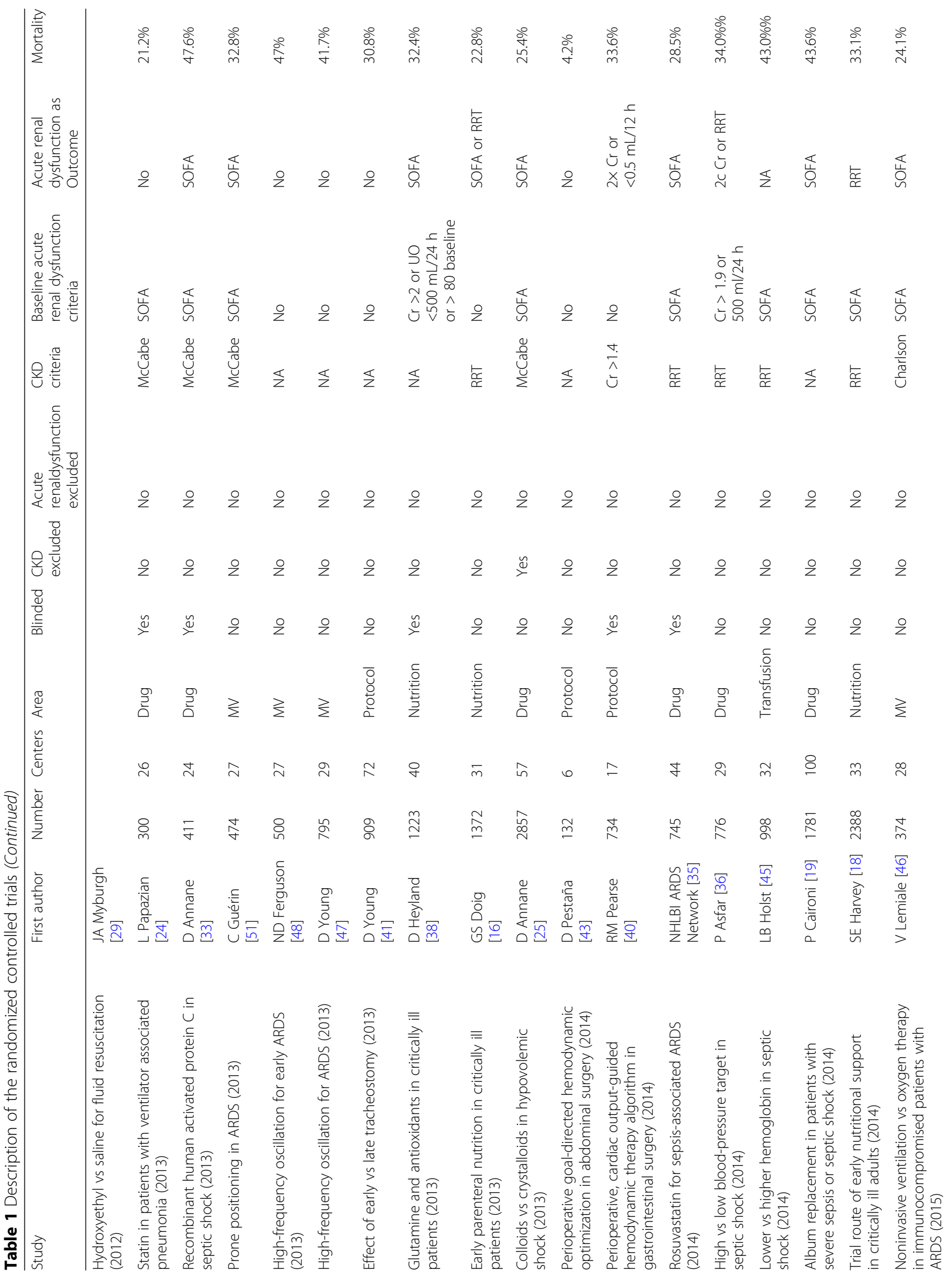




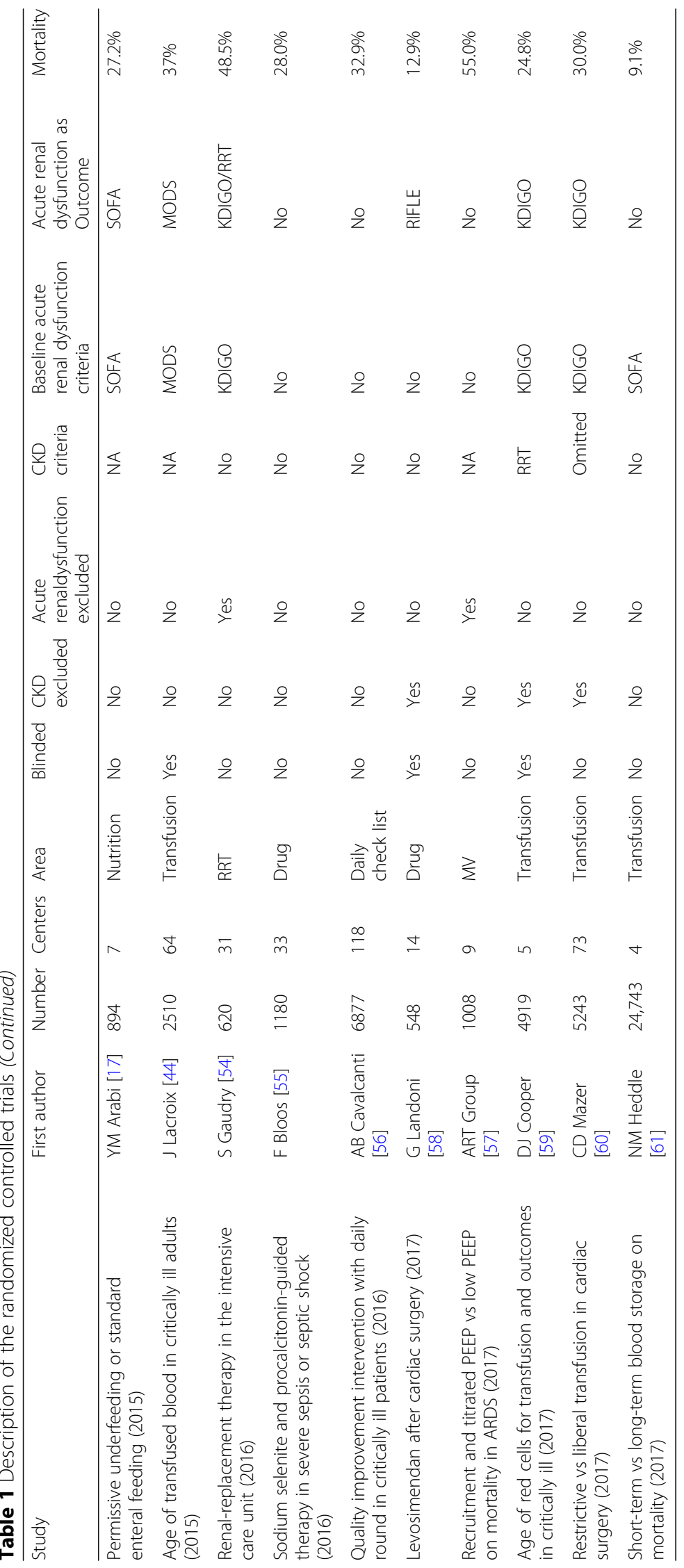




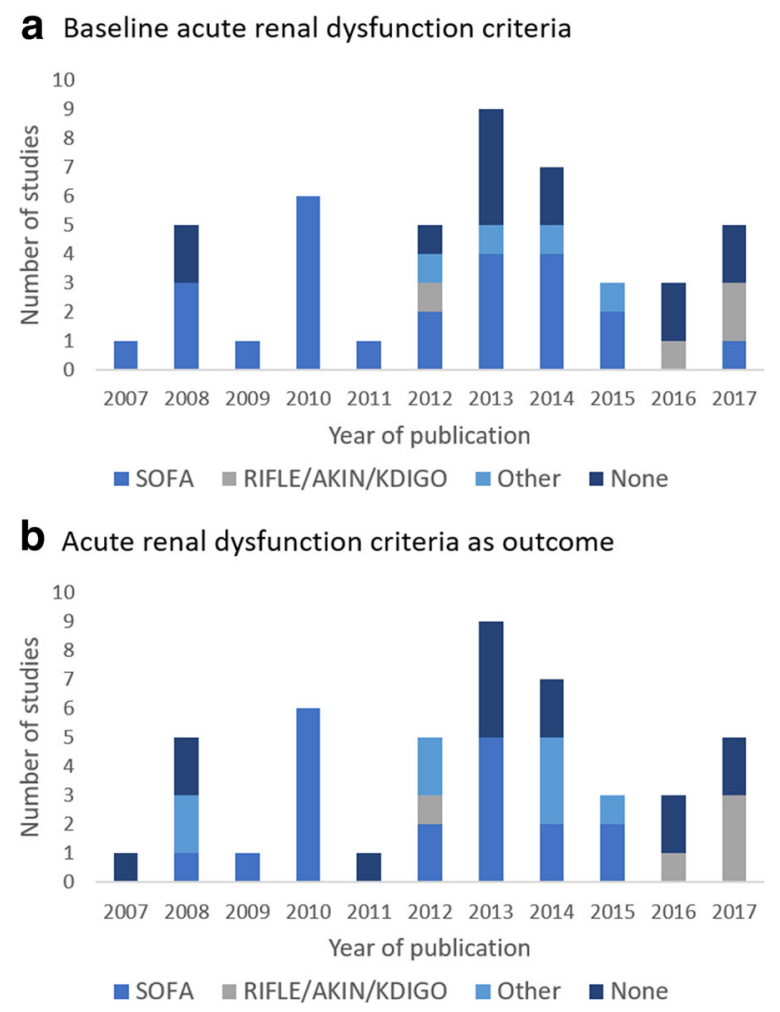

Fig. 2 Number of studies per year of publication stratified by baseline acute renal dysfunction criteria (a) and acute renal dysfunction criteria as outcome (b). SOFA, Sequential Organ Failure Assessment; RIFLE, Risk, Injury, Failure, Loss, End-stage renal disease; AKIN Acute Kidney Injury Network; KDIGO, Kidney Disease Improving Global Outcomes

to the parameters used to measure renal function, primarily creatinine concentration and urine output, because these parameters are frequently influenced by comorbidities, nutritional status, fluid overload and the overall severity of critical illness [62].

A single definition of acute renal dysfunction would be useful for clinical practice, research, and public health [13]. This definition has been rapidly changing in the literature since 2004 with the introduction of the RIFLE, AKIN, and KDIGO classification systems. These classifications were developed based on both evidence and consensus [63]. However, our findings show that with a few exceptions, they were not applied in RCTs with mortality as a primary outcome published in the period of this study. Furthermore, these systems were not widely used for defining or evaluating renal dysfunction as a secondary endpoint. These findings may raise concerns about the evidence-based use of these classification systems in the clinical management of critically ill patients. Nevertheless, it is important to notice that there was an apparent increase in the utilization of these scores in recent years (2016 and 2017).

Although the acute renal dysfunction (RIFLE/AKIN/ KDIGO) classification systems have been compared and validated [64], they do have certain limitations. First, the use of small changes in serum creatinine levels to diagnose AKI is limited by the high rates of false-positive diagnoses caused by the inherent variability of serum creatinine levels in patients with higher baseline values, thus potentially misclassifying patients with CKD [65]. Second, in contrast to individual measurements, efforts to determine the trajectory of serum creatinine levels can identify AKI sub-phenotypes with different mortality risks, even among patients with AKI of similar severity. These AKI sub-phenotypes might define patients at risk of poor outcomes (i.e., those with non-resolving AKI), who might benefit from novel interventions [66]. Third, renal dysfunction definitions that require a reference creatinine value to analyze baseline renal function should utilize a value that reflects steady-state kidney function prior to an AKI episode. When such reference values are not available, surrogate estimates are required, and these can affect the accuracy of the determination [67]. In contrast, the simplicity of the SOFA score and the objectivity of the variables required for its calculation make it useful for repeated measurements of the degree of organ dysfunction or failure [68].

The renal SOFA score was the most commonly used system to quantify renal function at baseline or as a secondary outcome. It may be more convenient to study changes in the SOFA score over time. Such changes have been assessed in critically ill patients over $48 \mathrm{~h}$ [69] or during treatment [70] and have also been used to evaluate the degree of organ dysfunction in sepsis [63]. In addition to assessing patient status, renal criteria can be used for prognosis. An early and sequential evaluation pattern (using any of the various scoring systems) has been shown to be a superior approach for prognostic scoring in critically ill patients who develop renal dysfunction compared with a single assessment at any time point during an ICU admission or stay [71]. Similarly, in patients with kidney injury, measuring changes in the SOFA score in the first $24 \mathrm{~h}$ of RRT can identify patients at high risk of mortality [72]. In contrast, individual SOFA scores are poor at predicting early (7 day) mortality in patients with septic AKI who require continuous RRT [73].

In addition to the new definitions of renal dysfunction, the SOFA score has been validated as a tool for assessing sequential organ dysfunction and is a good prognostic indicator. Furthermore, this score is familiar to critical care physicians and has been used for years in critical care settings and for different clinical conditions [69]. To date, no study has directly compared SOFA with RIFLE/AKIN/ KDIGO; however, the use of RIFLE criteria improved the performance of the Acute Physiology and Chronic Health Evaluation disease classification system II (APACHE II) score in predicting mortality in critically ill patients [74]. The prognostic value of a hypothetical score that 
combines RIFLE/AKIN/KDIGO criteria with the SOFA score, perhaps by replacing renal SOFA criteria variables with KDIGO criteria variables, is a matter of future research.

To our knowledge, the present manuscript is the first to describe the characterization of acute renal dysfunction in RCTs of critically ill patients. We have utilized an extensive search covering a period of 13 years following publication of current renal dysfunction definitions.

Nonetheless, our study does have several limitations. First, we have limited our sample to papers published in high-impact journals because these are typically multicenter studies with a better opportunity for impacting clinical practice [75]. We defined high-impact journals as those included in the MEDLINE core clinical journals subset [14]. The core clinical journals subset is an easy filter to apply. Using this filter, a MEDLINE search can focus on a set of journals selected for high quality and clinical utility, which may aid in the reproducibility of our findings, though we do recognize that there have been controversies as to the actual clinical utility of this subset [15]. However, because the new definitions of renal dysfunction are used at similar frequencies among the major journals, it is reasonable to assume that the addition of extra journals would not have meaningfully changed our results. In agreement with our methodology, other recently published reviews have utilized similar procedures [76, 77]. Nevertheless, this selection procedure may result in biases because papers published in journals with a lower impact factor may characterize renal dysfunction differently. Another limitation is that because we relied on published material as the typical information source for clinicians, we cannot exclude the possibility that some trials reported characterizations of renal dysfunction that differed from their original protocols [78].

\section{Conclusion}

The presence of renal dysfunction was included as a baseline patient characteristic and as an outcome measure in most multicenter RCTs involving critically ill patients with mortality as a primary endpoint that were published in core clinical journals in the study period. The analyzed RCTs generally defined acute renal dysfunction using the SOFA score, with a less frequent utilization of the RIFLE, AKIN and KDIGO classification systems. There is a need for further evaluation of the validity and barriers for utilization of each score to better inform clinical practice.

\footnotetext{
Abbreviations

AKI: Acute kidney injury; AKIN: Acute Kidney Injury Network; APACHE: Acute Physiology and Chronic Health Evaluation disease classification system; CKD: Chronic kidney disease; eGFR: Estimated glomerular filtration rate; GFR: Glomerular filtration rate; ICUs: Intensive care units; KDIGO: Kidney Disease Improving Global Outcomes; RCTs: Randomized controlled trials; RIFLE: Risk, Injury, Failure, Loss, End-stage renal disease; RRT: Renal replacement therapy; SOFA: Sequential Organ Failure Assessment
}

Acknowledgements

Not applicable.

\section{Funding}

This research did not receive any specific grants from funding agencies in the public, commercial, or not-for-profit sectors.

Availability of data and materials

All data generated or analyzed during this study are included in this published article.

\section{Authors' contributions}

RHP and PBP contributed to the design, acquisition, analysis, and interpretation of data and drafting and revising the manuscript. JGRR, AG, JC, and EM contributed to interpretation of data and drafting and revising the manuscript. All authors have read and approved the final version of this manuscript.

Authors' information

Not applicable.

Ethics approval and consent to participate

Not applicable.

Consent for publication

Not applicable.

\section{Competing interests}

The authors declare that they have no competing interests.

\section{Publisher's Note}

Springer Nature remains neutral with regard to jurisdictional claims in published maps and institutional affiliations.

\section{Author details}

${ }^{1}$ Critical Care Unit, Hospital São Rafael, Av São Rafael, Salvador 2152, Brazil. ${ }^{2}$ Department of Medicine, Division of Nephrology, University of California, San Diego, USA. ${ }^{3}$ Critical Care Unit, Nephrology Department, Hospital Portugues, Salvador, Brazil.

Received: 18 October 2017 Accepted: 28 February 2018 Published online: 24 April 2018

\section{References}

1. Susantitaphong P, Cruz DN, Cerda J, Abulfaraj M, Alqahtani F, Koulouridis I, Jaber BL. World Incidence of AKI: a Meta-Analysis. Clin J Am Soc Nephrol. 2013:8(9):1482-93

2. Bouchard J, Acharya A, Cerda J, Maccariello ER, Madarasu RC, Tolwani AJ, Liang $X$, Fu P, Liu ZH, Mehta RL. A prospective international multicenter study of $\mathrm{AKI}$ in the intensive care unit. Clin J Am Soc Nephrol. 2015;10(8):1324-31.

3. Vincent J-L, Marshall JC, Namendys-Silva SA, François B, Martin-Loeches I, Lipman J, Reinhart K, Antonelli M, Pickkers P, Njimi H, et al. Assessment of the worldwide burden of critical illness: the Intensive Care Over Nations (ICON) audit. Lancet Respir Med. 2014;2(5):380-6.

4. Cruz DN, Ronco C. Acute kidney injury in the intensive care unit: current trends in incidence and outcome. Crit Care. 2007;11(4):149.

5. Sawhney S, Fraser SD. Epidemiology of AKl: utilizing large databases to determine the burden of AKI. Adv Chronic Kidney Dis. 2017;24(4):194-204.

6. Thomas ME, Blaine C, Dawnay A, Devonald MAJ, Ftouh S, Laing C, Latchem S, Lewington A, Milford DV, Ostermann M. The definition of acute kidney injury and its use in practice. Kidney Int. 2015;87(1):62-73.

7. Singbartl K, Kellum JA. AKI in the ICU: definition, epidemiology, risk stratification, and outcomes. Kidney Int. 2012;81(9):819-25.

8. Pakula AM, Skinner RA. Acute kidney injury in the critically ill patient. J Intensive Care Med. 2015;31(5):319-24.

9. Palevsky PM, Liu KD, Brophy PD, Chawla LS, Parikh CR, Thakar CV, Tolwani AJ, Waikar SS, Weisbord SD. KDOQI US commentary on the 2012 KDIGO clinical practice guideline for acute kidney injury. Am J Kidney Dis. 2013;61(5):649-72.

10. Lameire N, Vanmassenhove J, Lewington A. Did KDIGO guidelines on acute kidney injury improve patient outcome? Intensive Care Med. 2017:43(6):921-3. 
11. de Mendonca A, Vincent $J$, Suter PM, Moreno R, Dearden NM, Antonelli M, Takala J, Sprung C, Cantraine F. Acute renal failure in the ICU: risk factors and outcome evaluated by the SOFA score. Intensive Care Med. 2000;26(7):915-21.

12. Ospina-Tascón GA, Büchele GL, Vincent J-L. Multicenter, randomized, controlled trials evaluating mortality in intensive care: doomed to fail? Crit Care Med. 2008;36(4):1311-22.

13. Kellum JA, Lameire N. Diagnosis, evaluation, and management of acute kidney injury: a KDIGO summary (Part 1). Crit Care. 2013;17(1):204.

14. New Look to PubMed's Subset Limit Pull-down Menu: Core clinical journals (used to be "AIM"). NLM Technical Bulletin. 2001;2001(319).

15. Klein-Fedyshin M, Ketchum AM, Arnold RM, Fedyshin PJ. Evaluating the MEDLINE Core Clinical Journals filter: data-driven evidence assessing clinical utility. J Eval Clin Pract. 2014;20(6):837-43.

16. Doig GS, Simpson F, Sweetman EA, Finfer SR, Cooper DJ, Heighes PT, Davies AR, O'Leary M, Solano T, Peake $S$, et al. Early parenteral nutrition in critically ill patients with short-term relative contraindications to early enteral nutrition: a randomized controlled trial. JAMA. 2013;309(20):2130-8.

17. Arabi YM, Aldawood AS, Haddad SH, Al-Dorzi HM, Tamim HM, Jones G, Mehta S, Mclntyre L, Solaiman O, Sakkijha MH, et al. Permissive underfeeding or standard enteral feeding in critically ill adults. N Engl J Med. 2015;372(25):2398-408.

18. Harvey SE, Parrott F, Harrison DA, Bear DE, Segaran E, Beale R, Bellingan G, Leonard R, Mythen MG, Rowan KM, et al. Trial of the route of early nutritional support in critically ill adults. N Engl J Med. 2014;371(18):1673-84.

19. Caironi P, Tognoni G, Masson S, Fumagalli R, Pesenti A, Romero M, Fanizza C, Caspani L, Faenza S, Grasselli G, et al. Albumin replacement in patients with severe sepsis or septic shock. N Engl J Med. 2014;370(15):1412-21.

20. Rice TW, Wheeler AP, Bernard GR, Vincent JL, Angus DC, Aikawa N, Demeyer I, Sainati S, Amlot N, Cao C, et al. A randomized, double-blind, placebocontrolled trial of TAK-242 for the treatment of severe sepsis. Crit Care Med. 2010;38(8):1685-94.

21. De Backer D, Biston P, Devriendt J, Madl C, Chochrad D, Aldecoa C, Brasseur A, Defrance $P$, Gottignies P, Vincent JL, et al. Comparison of dopamine and norepinephrine in the treatment of shock. N Engl J Med. 2010;362(9):779-89.

22. Investigators CS, Annane D, Cariou A, Maxime V, Azoulay E, D'Honneur G, Timsit JF, Cohen Y, Wolf M, Fartoukh M, et al. Corticosteroid treatment and intensive insulin therapy for septic shock in adults: a randomized controlled trial. JAMA. 2010;303(4):341-8.

23. Ranieri VM, Thompson BT, Barie PS, Dhainaut JF, Douglas IS, Finfer $S$, Gardlund B, Marshall JC, Rhodes A, Artigas A, et al. Drotrecogin alfa (activated) in adults with septic shock. N Engl J Med. 2012;366(22):2055-64.

24. Papazian L, Roch A, Charles PE, Penot-Ragon C, Perrin G, Roulier P, Goutorbe $P$, Lefrant JY, Wiramus $S$, Jung B, et al. Effect of statin therapy on mortality in patients with ventilator-associated pneumonia: a randomized clinical trial. JAMA. 2013;310(16):1692-700.

25. Annane D, Siami S, Jaber S, Martin C, Elatrous S, Declere AD, Preiser JC, Outin $H$, Troche G, Charpentier C, et al. Effects of fluid resuscitation with colloids vs crystalloids on mortality in critically ill patients presenting with hypovolemic shock: the CRISTAL randomized trial. JAMA. 2013;310(17):1809-17.

26. Kesecioglu J, Beale R, Stewart TE, Findlay GP, Rouby JJ, Holzapfel L, Bruins P, Steenken EJ, Jeppesen OK, Lachmann B. Exogenous natural surfactant for treatment of acute lung injury and the acute respiratory distress syndrome. Am J Respir Crit Care Med. 2009;180(10):989-94.

27. Sprung $C L$, Annane D, Keh D, Moreno R, Singer M, Freivogel K, Weiss YG, Benbenishty J, Kalenka A, Forst $\mathrm{H}$, et al. Hydrocortisone therapy for patients with septic shock. N Engl J Med. 2008;358(2):111-24.

28. Perner A, Haase N, Guttormsen AB, Tenhunen J, Klemenzson G, Aneman A, Madsen KR, Moller MH, Elkjaer JM, Poulsen LM, et al. Hydroxyethyl starch 130/0.42 versus Ringer's acetate in severe sepsis. N Engl J Med. 2012;367(2):124-34.

29. Myburgh JA, Finfer S, Bellomo R, Billot L, Cass A, Gattas D, Glass P, Lipman J, Liu B, McArthur C, et al. Hydroxyethyl starch or saline for fluid resuscitation in intensive care. N Engl J Med. 2012;367(20):1901-11.

30. Brunkhorst FM, Engel C, Bloos F, Meier-Hellmann A, Ragaller M, Weiler N, Moerer O, Gruendling M, Oppert M, Grond S, et al. Intensive insulin therapy and pentastarch resuscitation in severe sepsis. N Engl J Med. 2008;358(2):125-39.

31. Papazian L, Forel JM, Gacouin A, Penot-Ragon C, Perrin G, Loundou A, Jaber S, Arnal JM, Perez D, Seghboyan JM, et al. Neuromuscular blockers in early acute respiratory distress syndrome. N Engl J Med. 2010;363(12):1107-16.
32. Annane D, Vignon P, Renault A, Bollaert PE, Charpentier C, Martin C, Troche G, Ricard JD, Nitenberg G, Papazian L, et al. Norepinephrine plus dobutamine versus epinephrine alone for management of septic shock: a randomised trial. Lancet. 2007:370(9588):676-84.

33. Annane D, Timsit JF, Megarbane B, Martin C, Misset B, Mourvillier B, Siami S, Chagnon JL, Constantin JM, Petitpas F, et al. Recombinant human activated protein $C$ for adults with septic shock: a randomized controlled trial. Am J Respir Crit Care Med. 2013;187(10):1091-7.

34. Wunderink RG, Laterre PF, Francois B, Perrotin D, Artigas A, Vidal LO, Lobo SM, Juan JS, Hwang SC, Dugernier T, et al. Recombinant tissue factor pathway inhibitor in severe community-acquired pneumonia: a randomized trial. Am J Respir Crit Care Med. 2011;183(11):1561-8.

35. National Heart L, Blood Institute ACTN, Truwit JD, Bernard GR, Steingrub J, Matthay MA, Liu KD, Albertson TE, Brower RG, Shanholtz C, et al. Rosuvastatin for sepsis-associated acute respiratory distress syndrome. N Engl J Med. 2014;370(23):2191-200.

36. Asfar P, Meziani F, Hamel JF, Grelon F, Megarbane B, Anguel N, Mira JP, Dequin PF, Gergaud S, Weiss N, et al. High versus low blood-pressure target in patients with septic shock. N Engl J Med. 2014;370(17):1583-93.

37. Russell JA, Walley KR, Singer J, Gordon AC, Hebert PC, Cooper DJ, Holmes CL, Mehta S, Granton JT, Storms MM, et al. Vasopressin versus norepinephrine infusion in patients with septic shock. N Engl J Med. 2008;358(9):877-87.

38. Heyland D, Muscedere J, Wischmeyer PE, Cook D, Jones G, Albert M, Elke G, Berger MM, Day AG. Canadian Critical Care Trials G. A randomized trial of glutamine and antioxidants in critically ill patients. N Engl J Med. 2013; 368(16):1489-97.

39. Jansen TC, van Bommel J, Schoonderbeek FJ, Sleeswijk Visser SJ, van der Klooster JM, Lima AP, Willemsen SP, Bakker J. group Ls. Early lactate-guided therapy in intensive care unit patients: a multicenter, open-label, randomized controlled trial. Am J Respir Crit Care Med. 2010;182(6):752-61.

40. Pearse RM, Harrison DA, MacDonald N, Gillies MA, Blunt M, Ackland G, Grocott MP, Ahern A, Griggs K, Scott R, et al. Effect of a perioperative, cardiac output-guided hemodynamic therapy algorithm on outcomes following major gastrointestinal surgery: a randomized clinical trial and systematic review. JAMA. 2014;311(21):2181-90.

41. Young D, Harrison DA, Cuthbertson BH, Rowan K, TracMan C. Effect of early vs late tracheostomy placement on survival in patients receiving mechanical ventilation: the TracMan randomized trial. JAMA. 2013;309(20):2121-9.

42. Thiele H, Zeymer U, Neumann FJ, Ferenc M, Olbrich HG, Hausleiter J, de Waha A, Richardt G, Hennersdorf M, Empen K, et al. Intra-aortic balloon counterpulsation in acute myocardial infarction complicated by cardiogenic shock (IABP-SHOCK II): final 12 month results of a randomised, open-label trial. Lancet. 2013;382(9905):1638-45.

43. Pestana D, Espinosa E, Eden A, Najera D, Collar L, Aldecoa C, Higuera E, Escribano S, Bystritski D, Pascual J, et al. Perioperative goal-directed hemodynamic optimization using noninvasive cardiac output monitoring in major abdominal surgery: a prospective, randomized, multicenter, pragmatic trial: POEMAS Study (PeriOperative goal-directed thErapy in Major Abdominal Surgery). Anesth Analg. 2014;119(3):579-87.

44. Lacroix J, Hebert PC, Fergusson DA, Tinmouth A, Cook DJ, Marshall JC, Clayton L, McIntyre L, Callum J, Turgeon AF, et al. Age of transfused blood in critically ill adults. N Engl J Med. 2015;372(15):1410-8.

45. Holst LB, Haase N, Wetterslev J, Wernerman J, Guttormsen AB, Karlsson S, Johansson PI, Aneman A, Vang ML, Winding R, et al. Lower versus higher hemoglobin threshold for transfusion in septic shock. N Engl J Med. 2014; 371(15):1381-91

46. Lemiale V, Mokart D, Resche-Rigon M, Pene F, Mayaux J, Faucher E, Nyunga $M$, Girault C, Perez P, Guitton C, et al. Effect of noninvasive ventilation vs oxygen therapy on mortality among immunocompromised patients with acute respiratory failure: a randomized clinical trial. JAMA. 2015;314(16):1711-9.

47. Young D, Lamb SE, Shah S, MacKenzie I, Tunnicliffe W, Lall R, Rowan K, Cuthbertson BH, Group OS. High-frequency oscillation for acute respiratory distress syndrome. N Engl J Med. 2013;368(9):806-13.

48. Ferguson ND, Cook DJ, Guyatt GH, Mehta S, Hand L, Austin P, Zhou Q, Matte A, Walter SD, Lamontagne F, et al. High-frequency oscillation in early acute respiratory distress syndrome. N Engl J Med. 2013;368(9):795-805.

49. Mercat A, Richard JC, Vielle B, Jaber S, Osman D, Diehl JL, Lefrant JY, Prat G, Richecoeur J, Nieszkowska A, et al. Positive end-expiratory pressure setting in adults with acute lung injury and acute respiratory distress syndrome: randomized controlled trial. JAMA. 2008;299(6):646-55. 
50. Taccone P, Pesenti A, Latini R, Polli F, Vagginelli F, Mietto C, Caspani L, Raimondi $\mathrm{F}$, Bordone $\mathrm{G}$, lapichino $\mathrm{G}$, et al. Prone positioning in patients with moderate and severe acute respiratory distress syndrome: a randomized controlled trial. JAMA. 2009;302(18):1977-84.

51. Guerin C, Reignier J, Richard JC, Beuret P, Gacouin A, Boulain T, Mercier E, Badet M, Mercat A, Baudin O, et al. Prone positioning in severe acute respiratory distress syndrome. N Engl J Med. 2013;368(23):2159-68.

52. Meade MO, Cook DJ, Guyatt GH, Slutsky AS, Arabi YM, Cooper DJ, Davies $A R$, Hand LE, Zhou Q, Thabane $L$, et al. Ventilation strategy using low tidal volumes, recruitment maneuvers, and high positive end-expiratory pressure for acute lung injury and acute respiratory distress syndrome: a randomized controlled trial. JAMA. 2008;299(6):637-45.

53. Gao Smith F, Perkins GD, Gates S, Young D, McAuley DF, Tunnicliffe W, Khan Z, Lamb SE. investigators B-s. Effect of intravenous beta-2 agonist treatment on clinical outcomes in acute respiratory distress syndrome (BALTI-2): a multicentre, randomised controlled trial. Lancet. 2012;379(9812):229-35.

54. Gaudry S, Hajage D, Schortgen F, Martin-Lefevre L, Pons B, Boulet E, Boyer A, Chevrel G, Lerolle N, Carpentier D, et al. Initiation strategies for renal-replacement therapy in the intensive care unit. N Engl J Med. 2016;375(2):122-33.

55. Bloos F, Trips E, Nierhaus A, Briegel J, Heyland DK, Jaschinski U, Moerer O, Weyland A, Marx G, Grundling M, et al. Effect of sodium selenite administration and procalcitonin-guided therapy on mortality in patients with severe sepsis or septic shock: a randomized clinical trial. JAMA Intern Med. 2016;176(9):1266-76.

56. Writing Group for the C-ICUI, the Brazilian Research in Intensive Care N, Cavalcanti AB, Bozza FA, Machado FR, Salluh Jl, Campagnucci VP, Vendramim P, Guimaraes HP, Normilio-Silva K, et al. Effect of a quality improvement intervention with daily round checklists, goal setting, and clinician prompting on mortality of critically ill patients: a randomized clinical trial. JAMA. 2016;315(14):1480-90.

57. Writing Group for the Alveolar Recruitment for Acute Respiratory Distress Syndrome Trial I, Cavalcanti AB, Suzumura EA, Laranjeira LN, Paisani DM, Damiani LP, Guimaraes HP, Romano ER, Regenga MM, Taniguchi LNT, et al. Effect of lung recruitment and titrated positive end-expiratory pressure (PEEP) vs low PEEP on mortality in patients with acute respiratory distress syndrome: a randomized clinical trial. JAMA. 2017;318(14):1335-45.

58. Landoni G, Lomivorotov W, Alvaro G, Lobreglio R, Pisano A, Guarracino F, Calabro MG, Grigoryev EV, Likhvantsev W, Salgado-Filho MF, et al. Levosimendan for hemodynamic support after cardiac surgery. N Engl J Med. 2017:376(21):2021-31.

59. Cooper DJ, McQuilten ZK, Nichol A, Ady B, Aubron C, Bailey M, Bellomo R, Gantner D, Irving DO, Kaukonen KM, et al. Age of red cells for transfusion and outcomes in critically ill adults. N Engl J Med. 2017;377(19):1858-67.

60. Mazer CD, Whitlock RP, Fergusson DA, Hall J, Belley-Cote E, Connolly K, Khanykin B, Gregory AJ, de Medicis E, McGuinness S, et al. Restrictive or liberal red-cell transfusion for cardiac surgery. N Engl J Med. 2017;377(22):2133-44

61. Heddle NM, Cook RJ, Arnold DM, Liu Y, Barty R, Crowther MA, Devereaux PJ, Hirsh J, Warkentin TE, Webert KE, et al. Effect of short-term vs. long-term blood storage on mortality after transfusion. N Engl J Med. 2016:375(20):1937-45.

62. Weisbord SD, Palevsky PM. Design of clinical trials in acute kidney injury: lessons from the past and future directions. Semin Nephrol. 2016;36(1):42-52.

63. Singer M, Deutschman CS, Seymour CW, Shankar-Hari M, Annane D, Bauer M, Bellomo R, Bernard GR, Chiche J-D, Coopersmith CM, et al. The Third International Consensus Definitions for sepsis and septic shock (Sepsis-3). JAMA. 2016;315(8):801.

64. Fujii T, Uchino S, Takinami M, Bellomo R. Validation of the kidney disease improving global outcomes criteria for AKI and comparison of three criteria in hospitalized patients. Clin J Amer Soc Nephrol. 2014;9(5):848-54.

65. Lin J, Fernandez H, Shashaty MGS, Negoianu D, Testani JM, Berns JS, Parikh CR, Wilson FP. False-positive rate of AKI using consensus creatinine-based criteria. Clin J Amer Soc Nephrol. 2015;10(10):1723-31.

66. Bhatraju PK, Mukherjee P, Robinson-Cohen C, O'Keefe GE, Frank AJ, Christie JD, Meyer NJ, Liu KD, Matthay MA, Calfee CS, et al. Acute kidney injury subphenotypes based on creatinine trajectory identifies patients at increased risk of death. Crit Care. 2016;20(1):372.

67. Ostermann M, Joannidis M. Acute kidney injury 2016: diagnosis and diagnostic workup. Crit Care. 2016;20(1):299.

68. Arts DG, de Keizer NF, Vroom MB, de Jonge E. Reliability and accuracy of Sequential Organ Failure Assessment (SOFA) scoring. Crit Care Med. 2005; 33(9):1988-93.
69. Ferreira FL. Serial evaluation of the SOFA score to predict outcome in critically ill patients. JAMA. 2001;286(14):1754.

70. de Grooth H-J, Geenen IL, Girbes AR, Vincent J-L, Parienti J-J, Oudemans-van Straaten HM. SOFA and mortality endpoints in randomized controlled trials: a systematic review and meta-regression analysis. Crit Care. 2017;21(1):38.

71. Costa e Silva VT, de Castro I, Liaño F, Muriel A, Rodríguez-Palomares JR, Yu $\mathrm{L}$. Sequential evaluation of prognostic models in the early diagnosis of acute kidney injury in the intensive care unit. Kidney Int. 2009;75(9):982-6.

72. Cappi SB, Sakr Y, Vincent J-L. Daily evaluation of organ function during renal replacement therapy in intensive care unit patients with acute renal failure. J Crit Care. 2006;21(2):179-83.

73. da Hora PR, Ramos JGR, Mendonça EJB, Miranda EA, Dutra FRD, Coelho MFR, Pedroza AC, Correia LCL, Batista PBP, Macedo E, et al. A clinical score to predict mortality in septic acute kidney injury patients requiring continuous renal replacement therapy: the HELENICC score. BMC Anesthesiol. 2017;17(1):21.

74. Wahrhaftig KM, Correia LC, Matias D, De Souza CA. Does the RIFLE Classification improve prognostic value of the APACHE II score in critically ill patients? Int J Nephrol. 2013:2013:406165.

75. Gluud LL, Sorensen TI, Gotzsche PC, Gluud C. The journal impact factor as a predictor of trial quality and outcomes: cohort study of hepatobiliary randomized clinical trials. Am J Gastroenterol. 2005;100(11):2431-5.

76. Matino D, Chai-Adisaksopha C, Iorio A. Systematic reviews of prognosis studies: a critical appraisal of five core clinical journals. Diagn Progn Res. 2017;1(1):9. https://doi.org/10.1186/s41512-017-0008-Z.

77. Howard B, Scott JT, Blubaugh M, Roepke B, Scheckel C, Vassar M. Systematic review: outcome reporting bias is a problem in high impact factor neurology journals. PLoS One. 2017;12(7):e0180986.

78. Becker JE, Krumholz HM, Ben-Josef G, Ross JS. Reporting of results in ClinicalTrials.gov and high-impact journals. JAMA. 2014;311(10):1063-5.

\section{Submit your next manuscript to BioMed Central and we will help you at every step:}

- We accept pre-submission inquiries

- Our selector tool helps you to find the most relevant journal

- We provide round the clock customer support

- Convenient online submission

- Thorough peer review

- Inclusion in PubMed and all major indexing services

- Maximum visibility for your research

Submit your manuscript at www.biomedcentral.com/submit
C) Biomed Central 